\title{
Surgical experience in treatment of achalasia cardia with minimal invasive surgery
}

\author{
Ali A. Yassin ${ }^{1}$, Falih M. Al-Gazgooz ${ }^{2}$, \& Mazin H. Al-Hawaz ${ }^{3}$
}

\section{ABSTRACT}

Background: achalasia cardia is a motor disorder that result from absence of esophageal peristalsis combined with loss of relaxation of lower esophageal sphincter.

Aims: To analyze the safety of laparoscopic Heller's myotomy with particular regard to the technical difficulties encountered, complications, the learning curve and outcome.

Patients and methods: This study was done at Al - Sader Teaching Hospital, Basrah - Iraq in the period from February 2013 to June 2016. Thirty-two patients were included in the study of both gender and of different ages who were subjected to laparoscopic Heller's myotomy for achlasia cardia. They were observed regarding the development of operative and early post-operative complications, improvement of their symptoms, development of late post-operative complications and recurrence rate.

Results: All patients underwent laparoscopic Heller's myotomy with Dor fundoplication except one patient had Toupet fundoplication. The mean operative time was 87 minutes and the median hospital stay was four days. Intra- operative complications include mucosal perforation in 3 patients, vagus nerve injury in 3 patients, and pleural perforation in 2 patients. Post-operative complications include atelectasis in 3 patients, pneumonia in 1 patient, GERD in 1 patient, post-operative leak in one patient and mortality in one patient. All patients improved regarding dysphagia $(\mathbf{1 0 0 \% )}$ and weight gain achieved in $(\mathbf{9 1 . 3 \% )}$, chest pain improved in (59\%) and regurgitation improved in $(\mathbf{8 4 . 6 \% )}$ ) of the patients.

Conclusion: Laparoscopic Heller's myotomy is safe and effective method for treatment of achalasia cardia.

Key words: Achalasia cardia, Laparoscopy, Dysphagia

$$
\text { تجربه جراحية لعلاج تعذر الارتخاء المريئي بواسطه الجراحة المنظارية }
$$

الخلفية: تعذر الارتخاء المريئي هو اضطراب الحركة التي تنجم عن عدم وجود انقباضات المريء جنبا إلى جنب مع فقدان استرخاء مصرة البلعوم

الأهداف: لتحليل سلامة بضع تنظير العضل بالناضور مع إيلاء اهتمام خاص للصعوبات التقنية المصادفة، المضاعفات، ومنحني التعلم والنتائج.

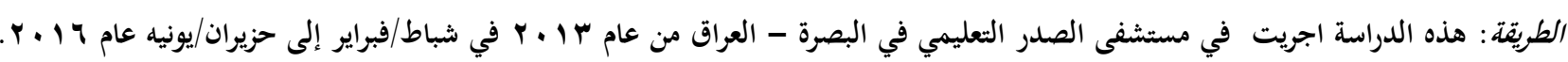

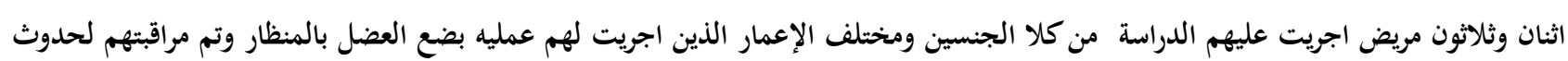

$$
\text { مضاعفات اثناء و بعد العملية وتحسن الاعراض المرضية ونسبه رجوع المرض. }
$$

الثنائج: اجريت العملية لجميع المرضى بالمنظار، معدل وقت العملية (AV) دقيقه، معدل الرقود في المستشفى اربعه ايام، المضاعفات اثناء العملية تشمل ثفب الغشاء المخاطي للمريئ في ثلاث مرضى، قطع العصب التائه في ثلاث مرضى، ثقب في غشاء الجنب في اثنان من المرضى، مضاعفات بعد العملية تشمل ذات الرئة في مريض واحد، ارتجاع مريئي في مريض واحد، تسريب المرئ في مريض واحد، وفاة في مريض واحد،

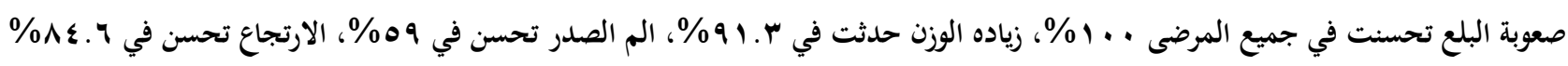

$$
\begin{aligned}
& \text { الاستنتاج: جراحه بضع العضل بالمنظار هي عمليه آمنه وفعاله لعلاج تعذر الارتخاء المريئي. }
\end{aligned}
$$

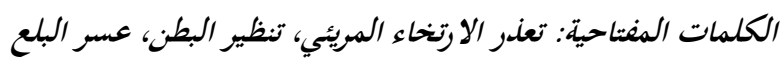

\footnotetext{
${ }^{1}$ Candidate of Iraqi Board

${ }^{2}$ MBChB.; FIBMS.; CABS.; FACS.; MRCS. Al-Sadder Teaching Hospital, Basrah, Iraq

${ }^{3}$ MBChB; DGS; CABS.; FRCS.(Glasgow); Head of Department of surgery, Dean of Al-Zahraa College of Medicine, University of Basrah
} 


\section{INTRODUCTION}

A chalasia cardia is a primary motor disorder that is characterized by loss of peristalsis of the esophageal body and absence relaxation of the lower esophageal sphincter. [1] It is manifested by dysphagia, regurgitation, retrosternal chest pain and weight loss. ${ }^{[2]}$ It is a rare condition affecting 1 in 100,000 individuals, there are neither racial nor gender differences in its incidence according to epidemiological studies. ${ }^{[3]}$ Although the cause of achalasia is still not clear, the principle of its treatment has been evident since 1900, that is disruption of lower esophageal sphincter to relieve dysphagia . ${ }^{[3]}$ In general, the treatment methods for esophageal achalasia are classified into four groups, including drug therapy using nitrite or a calcium channel blocker, botulinum toxin injection, endoscopic balloon dilatation and surgery, which include laparotomy, thoracotomy, thoracoscopy and laparoscopy. ${ }^{[4]}$ Many studies have suggested that the most effective treatment of esophageal achalasia is surgical therapy by laparoscopic Heller's myotomy because of its simplicity and superior outcome. ${ }^{[4,5]}$ Many questions have been raised over the past decade regarding outcome after laparoscopic Heller's myotomy, including the long term relive of dysphagia, the frequency and severity of gastro-esophageal reflux, the rate of success and failure, and the need of reintervention and revision after myotomy. ${ }^{[5-6]}$

This study aims to analyze the safety of laparoscopic Heller's myotomy with particular regard to the technical difficulties encountered, complications, the learning curve and outcome.

\section{PATIENTS AND METHODS}

This is a retro and prospective study was done on 32 patients diagnosed with acahalasia cardia who were subjected to laparoscopic Heller's myotomy with Dor or Toupet fundiplication at Al Sader Teaching Hospital Basrah - Iraq in the period from February 2013 to June 2016 with a follow up period for two years, among them 18 patients were females $(56.25 \%)$ and 14 patients were males $(43.75 \%)$ with a median age was (34.5) years range from (8-61) years. All patients presented with dysphagia, weight loss in 23 patients, retrosternal chest pain in 22 patients and regurgitation in 13 patients. Only one patient had previous treatment with balloon dilatation. Most of patients were diagnosed by history and clinical examination, barium swallow, manometry and endoscopic examination to exclude malignancy and other esophageal pathology in addition to all relevant pre-operative hematological, biochemical, cardiac and respiratory investigations were also done. All patients underwent the surgery under general anesthesia and they were placed in French position with the surgeon stand between the patients legs, five ports were inserted in the upper abdomen as shown in (Figure-1), the dissection started by incising a vascular area of gastro hepatic omentum above the hepatic branch of vagus nerve to expose the right crus of diaphragm, after identification of the gastroesophageal junction and cutting of the short gastric vessels and exposure of left crus of diaphragm ,mobilization of the esophagus was done. Myotomy was started after mobilization of about $8 \mathrm{~cm}$ of lower esophagus after identification and preservation of anterior and posterior vagus nerve by using both blunt and sharp dissection by harmonic energy device with care not to injured the mucosa, the myotomy extended about $2 \mathrm{~cm}$ on the gastric side and $6 \mathrm{~cm}$ on the esophageal side and followed by gastric fundoplication to prevent gastro-esophageal reflux. Anterior Dor fundiplication was done in all patients except one patient in whom posterior Toupet fundiplication was done because the patient had wide hiatus. Post operatively all patients were kept on intra venous fluids antibiotics and analgesia and observed for any signs of bleeding, leak, peritonitis and respiratory complications like atelectasis and pneumonia. 
Oral fluid started at the first post-operative day, except for the patients who had mucosal injury diagnosed during surgery, the mucosal injury were sutured with vicryl 3-0 and methylene blue test were done to confirm that there is no leak and drain kept for 3-5 days, a gastrograffin swallow was done after 48-72 hour of surgery and oral fluid started after confirmation of no contrast extravasations. The patients discharged 2-6 days after surgery and asked to remain on soft diet for two weeks. The first visit to the hospital was after (7-10) days from the surgery when sutures were removed and the patients evaluated regarding their dysphagia, vomiting, regurgitation and development of respiratory complications. The second visit to the hospital was after three months from the surgery when barium swallow was done. The third postoperative visit to the hospital was after 6 months after surgery and upper endoscopic examination was done if the patient complaining from dysphagia, regurgitation and chest pain. Then the patients were followed every 6 months and evaluated for the development of late complications like recurrence and gastro esophageal reflux.

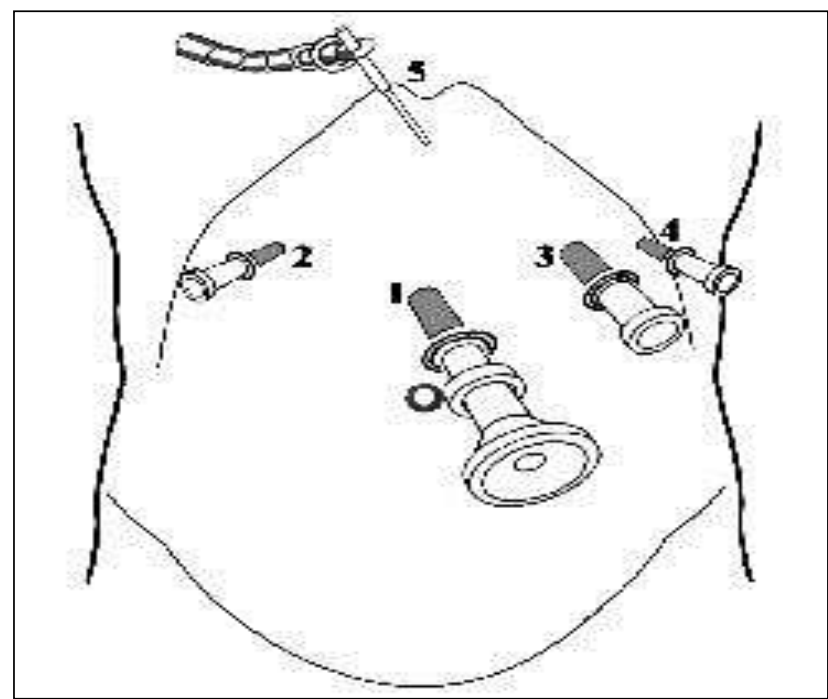

Fig 1. Ports site: (1) camera $(2,3)$ surgeon working ports (4) assistant port (5) liver retractor (Taken from lecture of Prof. R.K.Mishra, How to do laparoscopic fundoplication)

\section{RESULT}

This study was done on 32 patients, 18 were females and 14 were males with median age of (34.5)years ranged from (8-61) years, as in (Table-1)

Table 1. Sex and age distribution of patients.

\begin{tabular}{||c|c|c|c|c|c|c||}
\hline \hline Total number & Female & $\mathbf{\%}$ & Male & Median age (year) & $\boldsymbol{\%}$ & Median age (year) \\
\hline 32 & 18 & 56.25 & 14 & 32.5 & 43.75 & 36.5 \\
\hline
\end{tabular}

The presenting symptoms were dysphagia, retrosternal chest pain, weight loss and regurgitation. All operations were completed laparoscopicaly, no conversion to open surgery. The mean operative time was (87) minutes ranged from (55) minutes to (120) minutes, as in (Table-2)

Table 2. Operative time.

\begin{tabular}{||c|c||}
\hline Patient & Operative time in minute \\
\hline $\mathbf{1}^{\text {st }}$ ten patients & $110-120$ minute \\
\hline $\mathbf{2}^{\text {nd }}$ twelve patients & $80-90 \quad$ minute \\
\hline Last ten patients & $55-60 \quad$ minute \\
\hline
\end{tabular}

The intra operative complications were mucosal perforation in three patients $(9.37 \%)$, two of them diagnosed during surgery and the third one diagnosed after surgery, anterior vagus nerve injury in two patients $(6.25 \%)$ and posterior vagus nerve injury in one patient $(3.12 \%)$, pleural perforation in two patients $(6.25 \%)$ and no solid organ injury or intra operative bleeding, as shown in (Table-3) 
Table 3. Intra operative complications.

\begin{tabular}{||l|c|c||}
\hline \multicolumn{1}{|c|}{ Type of complication } & $\begin{array}{c}\text { No. of } \\
\text { patient }\end{array}$ & $\%$ \\
\hline Mucosal perforation & 3 & 9.37 \\
\hline Anterior vagus nerve injury & 2 & 6.25 \\
\hline Posterior vagus nerve injury & 1 & 3.12 \\
\hline Pleural perforation & 2 & 6.25 \\
\hline Solid organs injury & 0 & 0 \\
\hline Intra operative bleeding & 0 & 0 \\
\hline Total & 8 & 25 \\
\hline
\end{tabular}

Early post-operative complications occurred in five patients, three patients developed atelectasis $(9.37 \%)$, one patient developed pneumonia (3.12\%), and one patient developed post-operative leak $(3.12 \%)$ and he was died in the fifth post-operative day, mortality rate is $(3.12 \%)$ and there was no post-operative bleeding, As in (Table-4)

Table 4. Early Post-operative complications

\begin{tabular}{||l|c|c||}
\hline \multicolumn{1}{|c|}{ Type of complication } & $\begin{array}{c}\text { No. of the } \\
\text { patient }\end{array}$ & \% \\
\hline Atalectasis & 3 & 9.37 \\
\hline Pneumonia & 1 & 3.12 \\
\hline Post-operative leak & 1 & 3.12 \\
\hline Post-operative bleeding & 0 & 0 \\
\hline Total & 5 & 18.73 \\
\hline
\end{tabular}

Late post-operative complications developed in one patients (3.22\%) who developed GERD six months after surgery and there was no recurrence as in (Table-5).

Table 5. Late post-operative complications.

\begin{tabular}{|c|c|c||}
\hline Type of complication & $\begin{array}{c}\text { No. of } \\
\text { patients }\end{array}$ & $\%$ \\
\hline GERD & 1 & 3.22 \\
\hline Recurrence & 0 & 0 \\
\hline Total & 1 & 3.22 \\
\hline
\end{tabular}

The median hospital stay was four days ranged from (2-6) days. Regarding the improvement of pre-operative symptoms, there was no dysphagia in 29 patients $(93.54 \%)$ and mild dysphagia in 2 patients $(6.45 \%)$, weight gain in 21 patients $(91.3 \%)$, pain decrease in13 patients $(59 \%)$ and regurgetation improved in 11 patients $(84.6 \%)$, as in (Table-6).

Table 6. Post-operative improvement of symptoms.

\begin{tabular}{|c|c|c|c|c|}
\hline Pre-operative symptoms & No. of patient & $\%$ & Post-operative improvement & $\%$ \\
\hline \multirow{2}{*}{ Dysphagia } & \multirow{2}{*}{31} & \multirow{2}{*}{100} & No dysphagia 29 & 93.54 \\
\hline & & & Mild dysphagia 2 & 6.45 \\
\hline Weight loss & 23 & 74.1 & 21 & 91.3 \\
\hline Pain & 22 & 70.9 & 13 & 59 \\
\hline Regurgitation & 13 & 41.9 & 11 & 84.6 \\
\hline
\end{tabular}

*One patient was died and excluded from the result of post-operative improvement of symptoms 


\section{DISCUSSION}

Achalasia cardia is a rare disease, and not diagnosed until several years from its first symptoms because of the slow progression of the disease and symptoms are often confused with gastro- esophageal reflux disease or simple dysphagia. ${ }^{[7,11]}$ All methods of treatment of achlasia cardia aims to relief symptoms, with no treatment reverse the underlying neuropathological changes. ${ }^{[8-9]}$ Minimally invasive Heller's myotomy has becomes gold standard procedure in the treatment of achalasia cardia and have many advantages over thoracotomy and laparotomy in a form of decrease post-operative pain, morbidity, hospital stay and also it provide advantages of better visualization of surgical field and better identification of important structures such as vagus nerve, blood vessels, gastroesophageal junction and minute mucosal perforation because of magnification provided by laparoscopy. ${ }^{[9]}$ Another controversy related to the type of fundoplication that done with Heller's myotomy, most of surgeons agreed that Nissen fundoplication lead to dysphagia and they recommend partial wrap. ${ }^{[8.9]}$ The Toupet posterior fundoplication has advantages of preventing closure of myotomy by fixing the gastric fundus to the both edges of myotomy and has better post-operative reflux control in supine position, but it is technically more difficult to do than the anterior Dor fundoplication and takes more operative time. ${ }^{[10]}$ The Dor fundoplication is technically easer to perform and takes less time and it covers the exposed esophageal mucosa after myotomy and has good reflux control. ${ }^{\left[{ }^{[-10]}\right.}$ The most common intra operative complication in all studies as in our study is mucosal perforation which was occurred in three patients $(9.37 \%)$ which is nearly similar to result of a study done in India by Lileswar Kaman in which mucosal perforations were $12 \%$. $^{[1]}$ In our study two mucosal perforations were diagnosed during surgery and were sutured with vicryl 3-0 and methylene blue test was done to confirm that there is no leak and drain were kept for 3-5 days. One patient had perforation that was diagnosed by water soluble contrast in the third post-operative day which had been done because of persistent fever and tachycardia and the study showed active leak, laparoscopic exploration was done and mucosal perforation was sutured with vicryl 3-0 after washing of peritoneal cavity with normal saline, drain was kept and jejunostomy feeding tube was inserted, but unfortunately the patient died after two days because of mediastinitis, sepsis and multi-organ failure. In our study mortality was occurred in one patient $(3.12 \%)$, which is higher than the result of the studies done by Lileswar Kaman, and Kamil Gulpinar, in both studies they have no mortality. ${ }^{[11-12]}$ Two patients had anterior vagus nerve injury and one patient had posterior vagus nerve injury and pyloroplasty had done for them. Two patients had pleural perforation that had been identified during surgery and evacuated through a trocar site with tube drain placed across the perforation and removed at the end of surgery. In comparison with the studies done by Lileswar Kaman and Kamil Gulpinar both have no vagus nerve injury and no pleural perforation. ${ }^{[11-12]}$ All the patients improved regarding dysphagiea, with $(93.54 \%)$ of the patient had no dysphagiea and $(6.45 \%)$ had mild dysphgeia which is similar to result of the studies done by Lileswar Kaman and Kamil Gulpinar. ${ }^{[11,12]}$ Post-operative GERD occurred in one patient $(3.12 \%)$ which is slightly lower than the study done by Kamil Gulpinar where GERD was $7.5 \%{ }^{[12]}$ The mean operative time was 87 minutes which is nearly similar to the operative time in the study done by lileswar Kaman where the mean operative time was 93.3 minutes. $^{[11]}$

\section{CONCLUSION}

Laparoscopic heller's myotomy is safe and effective method for treatment of achalasia 
cardia and Dor fundiplication is quick, simple, effective in prevent GERD and not associated with increase rate of dysphageia.

\section{REFERENCES}

1. Neyaz Z, Gupta M, Mahesh, Ghoshal C. How to Perform and Interpret Timed Barium Esophagogram. Journal of Neurogastroenterology and Motility, 2013, 19.2: 251-256.

2. Constantinoiu S, Mates I, Dinu D, Iosif C, Cociu L, Anghel R, et al. Pseudo-achalasic behavior of a middle thoracic esophageal squamous cell carcinoma. Chirurgia (Bucur). 2008; 103(5): 595-600.

3. Cheatham J, Wong R. Current approach to the treatment of achalasia. Current gastroenterology reports, 2011, 13.3: 219-225.

4. Mayberry J. Epidemiology and demographics of achalasia. Gastrointest Endosc Clin N Am. 2001; 11:235-248.

5. Podas T, Eaden J, Mayberry M, Mayberry J. Achalasia: a critical review of epidemiological studies. Am J Gastroenterol. 1998; 93: 2345-2347.
6. Ramacciato G, Mercantini P, Amodio PM, et al. Minimally invasive surgical treatment of esophageal achalasia . JSLS. 2003; 7: 219-225.

7. Arber N. Epidemiology of achalasia in central Israel: rarity of esophageal cancer. Dig Dis Sci. 1993; 38: 1920-1929.

8. Abir F, Modlin I, Kidd M, Bell R. Surgical treatment of achalasia: current status and contaversies. Dig surg. 2004; 21: 165-176.

9. Perrone J,Frisella M, Desai K, Soper N. Result of laparoscopic heller-Toupet operation for achalasia. Surg Endosc. 2004; 18: 1565-1571.

10. Patti MG, Pellegrini CA, Horgan $S$, et al. Minimally invasive surgery for achalasia an 8year experience with 168 patients. Ann surg. 1999; 230: 587-594.

11. Lileswar K, Javid I, Rakesh K, Saroj S. Laparoscopic Heller Myotomy for Achalasia Cardia-Initial Experience in a Teaching Institute. Indian Journal of Surgery, 2013, 75.5: 391-394.

12. Kamil G ,Haydar C, Ulas S, Ahmet Tl. The therapeutic results after laparoscopic hellers' myotomy and partial fundoplication for achalasia. The Turkish journal of gastroenterology: the official journal of Turkish Society of Gastroenterology, 2014, 25: 54-58. 